\title{
The Relationship between CRP Levels and Gastritis in Children with or without Helicobacter pylori Infection
}

\author{
M. Azhariy Daulay ${ }^{a}$, Supriatmo ${ }^{b}$, Aridamuriany D. Lubis ${ }^{c}$, Isti Fujiatid ${ }^{d}$ Oke Rina \\ Ramayanie, Tina C L Tobing ${ }^{\mathrm{f}}$ \\ amadaulay@gmail.com \\ ${ }^{a}$ Resident of Department of Child Health, Medical School, Universitas Sumatera Utara/Universitas Sumatera Utara Hospital/Adam Malik \\ Hospital, Jl. dr. Mansyur No. 5, Medan 20155, Indonesia \\ ${ }^{b}$ Gastroenterology Consultant of Department of Child Health, Medical School, Universitas Sumatera Utara/Universitas Sumatera Utara \\ Hospital/Adam Malik Hospital, J1. dr. Mansyur No. 5, Medan 20155, Indonesia \\ ${ }^{c}$ Pediatric Emergency and Intensive Care Consultant of Department of Child Health, Medical School, Universitas Sumatera Utara/Universitas \\ Sumatera Utara Hospital/Adam Malik Hospital, J1. dr. Mansyur No. 5, Medan 20155, Indonesia \\ ${ }^{\mathrm{d}}$ Public Health of Department of Child Health, Medical School, Universitas Sumatera Utara/Universitas Sumatera Utara Hospital/Adam Malik \\ Hospital, Jl. dr. Mansyur No. 5, Medan 20155, Indonesia \\ ${ }^{\mathrm{e}}$ Nephrology Consultant of Department of Child Health, Medical School, Universitas Sumatera Utara/Universitas Sumatera Utara \\ Hospita1/Adam Malik Hospital, J1. dr. Mansyur No. 5, Medan 20155, Indonesia \\ ${ }^{\mathrm{f}}$ Cardiology Consultant of Department of Child Health, Medical School, Universitas Sumatera Utara/Universitas Sumatera Utara Hospital/Adam \\ Malik Hospital, J1. dr. Mansyur No. 5, Medan 20155, Indonesia
}

\begin{abstract}
Background: Helicobacter pylori infection is the most causes of gastritis in the world. A combination of clinical symptoms, physical examination, and supporting laboratories are needed to determine the severity of gastritis. Gastritis is a chronic inflammation that causes an increase in inflammatory markers. C reactive protein (CRP) as one of the markers of inflammation that is able to describe inflammation objectively, and evaluate its changes. Previous studies have shown that H.pylori infection causes increased CRP concentrations.

Methods: This study is a cross sectional of data on children who are treated in the Gastrohepatology division aged 2-18 years old, that have been diagnosed with gastritis through endoscopic examination with CLO measurements, and have CRP level, according to inclusion and exclusion criteria. The data with gastritis were further divided into positive H.pylori and negative H.pylori. The caracteristics of children and parents were recorded.

Result: This study involved 62 data children who met the inclusion and exclusion criteria. From the CLO examination, there were 30 children with positive H.pylori and 32 children with negative H.pylori. the dominant clinical symptom in both groups was recurrent abdominal pain, but there was no significant difference between them. The mean CRP value obtained in the positive H.pylori group was 36,78 , while in the negative H.pylori group it was 11,73 . There were significant differences in CRP valus between them $(\mathrm{p}<0,001)$.

Conclusion: There was an association between CRP levels in pediatric gastritis with H.pylori infection compared to without H.pylori infection.
\end{abstract}




\section{Introduction}

Helicobacter pylori (H. pylori) infection is one of the causes of gastritis in most of the world's population. These bacteria can colonize the gastric mucosa and cause mucosal inflammation that triggers gastritis (Ruggiero P, et al., 2010). H. pylori bacteria is a gram-negative, spiral-shaped bacterium, which was discovered in the stomach by Warren and Marshall in 1982 and has opened new insights into the causes of gastric disorders digestion (Hegar, 2000).

Prevalence of H.pylori infection in children ranges from $30-80 \%$ in developing countries. It is aproximately estimated $50 \%$ of the world's population is infected by H.pylori. The prevalence in Asia was reported from $8.2 \%$ to $11 \%$, while in Jakarta, the prevalence of H.pylori infection based on serological examinations in 150 elementary school students was $27 \%$, and $90 \%$ of those who were seropositive had H.pylori in their stomach (Hegar, 2000).

H. pylori infection can cause stomach inflammation (gastritis) in children and non-specific clinical symptoms (asymptomatic) throughout their life. The transmission of H. pylori is still unknown. Close contact with an H.pylori-infected individual either orally, gastro-oral, or fecal-oral is considered a form of H.pylori transmission (Plunkett, et al. 2005). Crowded environment and low socioeconomic environment are considered as risk factors for H.pylori infection in children. Infected parents, especially mothers, may play a role in the transmission of H. pylori in the family. Flies and cockroaches are suspected as vectors of H.pylori (Sierra D, et al.,2018).

H. pylori tends to settle irregularly in the stomach antrum because it lacks acid. H. pylori attracts neutrophils and lymphocytes with several chemotactic proteins released by the stomach. Several substances secreted by mononuclear cells and neutrophils cause mucosal inflammation and cause gastritis (Guclu M, eta., 2017). Gastritis is a chronic inflammatory process associated with elevated serum inflammatory markers, such as interleukin, c reactive protein (CRP), platelets, and neutrophils (Saribas S, et al., 2004). Of these markers, CRP is a protein that appears in the acute phase that is commonly used in acute systemic conditions (Altun E, et al., 2019) and some chronic inflammatory conditions (Raut, et al., 2015).

C-Reactive Protein (CRP) is one of the acute phase proteins found in blood serum even in small concentrations. CRP concentrations can increase up to 100 times which can be caused by infectious or noninfectious diseases. CRP will increase in serum if there is an inflammatory process where the liver is the main organ for CRP synthesis (Briggs, et al., 2013). C-reactive protein circulating in the blood circulation is a disc shaped pentamer and undergoes dissociation due to exposure to bioactive lipids in the platelet cell membrane which is activated from cells that are activated. necrosis and apoptosis. As a result, mCRP (CRP monomer) then exerts a proinflammatory effect. The mechanism that causes the higher CRP concentrations in H. pylori infection remains to be determined. Research shows that H. pylori infection increases CRP concentrations, which suggests an important role for H. pylori infection (Kingsley, et al., 2008).

Establishing the diagnosis and classification of gastritis severity requires a combination of clinical symptoms, physical examination and support. Supportive examinations such as CRP can assess disease from different aspects, namely measuring the level of inflammation objectively (Vermeire, et al., 2005). C reactive protein plays a clinical and biological role so that it can assist in making a diagnosis and evaluating clinically according to the inflammatory condition in the patient. regarding the relationship of CRP values in childhood gastritis with and without H. pylori infection. There has been no research on differences in CRP values in gastritis in children with and without H. pylori infection at H. Adam Malik Hospital and USU Hospital and Network Hospital in Medan.

\section{MATERIALS AND METHODS}

This study is a diagnostic study with a cross-sectional study approach. The research was conducted at RSUP.H. Adam Malik (HAM) Medan, University Sumatra Utara (USU) Hospital. The study was conducted in December 2020. This study involved 62 children with the inclusion criteria for outpatient and hospitalized patients aged 2 years to $<18$ years who had been diagnosed gastritis thorugh endoscopic and CLO (campylobacter like organism) examinations. In addition, the children had also been tested for CRP. The exclusion criteria in this study are experiencing absolute contraindications to endoscopy including bowel perforation and relative contraindications, bleeding disorders and / or platelet disorders, neutropenia, patients at risk of perforation. Patients used drugs such 
as proton pump inhibitors (PPIs), H2 blocker antagonists, antibiotics and / or NSAIDs in the last 14 days. In addition, children with a history of malignancy and immunodeficiency were excluded from the study

The data in this study have been processed and analyzed using SPSS version 23. All research data have been recapitulated and presented in the form of general characteristics (descriptive) first. Hypothesis testing for comparison of two unpaired groups (between the gastritis group with or without H. pylori) was performed using the T-test, and if the data were not normally distributed, the Mann Whitney test was used. Test the normality of the data using the Saphiro-Wilk test. The significance of the statistical test results was determined based on the P value $<0.05$ with a $95 \%$ confidence level.

This study was approved by the Research Ethics Committee of the Faculty of Medicine, University Sumatera Utara. All research subjects were asked for consent from parents after prior explanation referring condition of the disease experienced and the examinations that had been carried out. Afterwards, the patient is asked for information for baseline patient characteristics.

\section{RESULTS}

This study was followed by 62 children aged 2-18 years who had been diagnosed with gastritis at the Pediatric Gastroenterohepatology section of H. Adam Malik Hospital Medan, University of North Sumatra Hospital, and network hospitals who had met the inclusion and exclusion criteria. The results of the CLO examination found about 30 children were $\mathrm{H}$. pylori positive and 32 children with $\mathrm{H}$. pylori were negative. Table 1 shows the demographic characteristics of all subjects in this study.

A total of 30 children with $\mathrm{H}$. pylori were positive, 19 children (63.3\%) were female, while 32 children with H. pylori was negative, 19 children (59.4\%) were female. By using the Chi Square test, there was no difference in the proportion of sex in the two study groups $(\mathrm{p}=0.749)$. The mean age of children with $\mathrm{H}$. pylori positive was 11.48 years and the mean age of children with $\mathrm{H}$. pylori negative was 11.83 years. There was no significant age difference $(\mathrm{p}=0.789)$ between the two study groups after being analyzed using the Mann Whitney test.

Based on ethnicity, it can be seen that the Batak tribe was dominant in two groups, as many as 12 people $(40 \%)$ in the H. pylori group were positive and 13 people $(40.6 \%)$ in the H. pylori negative group. There was no difference in the proportion of ethnic groups $(\mathrm{p}=0.746)$ in the two study groups after being tested with Kruskal Wallis. A good socioeconomic level was dominant in two groups, where in the positive H. pylori group there were 27 people (90\%) and 28 people (87.5\%) in the negative H. pylori group. By using Fischer's Exact test, there was no difference in socioeconomic level in the two study groups $(\mathrm{p}=1,000)$.

The education of children in the $\mathrm{H}$. pylori positive group was junior high school, as many as 11 people (36.7\%) and in the negative H. pylori group the education level of elementary and junior high school was 11 people (34.4\%). There was no significant difference in the level of children's education in the two study groups $(\mathrm{p}=0.999)$ after being analyzed using the Kruskal Walli test. The education level of the majority of fathers and mothers is tertiary education (PT) in two groups. There was no significant difference in the level of education of the subject's father and mother in the two study groups ( $\mathrm{p}>0.05$ ).

Most of the subjects in the two groups had a family history of gastritis, as many as 22 children (73.3\%) in the $\mathrm{H}$. pylori positive group and as many as 20 children $(62.5 \%)$ in the $\mathrm{H}$. pylori negative group. There was no significant difference in family history between the two study groups $(p=0.362)$. In addition, table 2 shows of Clinical Characteristics of Subjects in this study.

The mean weight and height in the group of children with positive H. pylori were $37.10 \mathrm{~kg}$ and 138.53 $\mathrm{cm}$, while in the group of children with $\mathrm{H}$. pylori negative were $37.08 \mathrm{~kg}$ and $136.5 \mathrm{~cm}$, respectively. There was no difference in mean weight or height between the two groups ( $p>0.05)$.

The most common clinical symptom was recurrent abdominal pain in the two groups, about 17 (56.7\%) children in the $\mathrm{H}$. pylori positive group and 19 (59.3\%) children in the H. pylori negative group. There was no significant difference in clinical symptoms between the two study groups $(\mathrm{p}=0.135)$. 
Table 1. Demographic Characteristics of Subjects

\begin{tabular}{|c|c|c|c|}
\hline \multirow{2}{*}{ Subject Characteristics } & \multicolumn{2}{|c|}{ H. pylori } & \multirow{2}{*}{$\mathbf{p}$} \\
\hline & $(+) n=30$ & $(-) n=32$ & \\
\hline \multicolumn{4}{|l|}{ Sex, n (\%) } \\
\hline Man & $11(36,7)$ & $13(40,6)$ & \multirow[t]{2}{*}{$0,749^{\mathrm{a}}$} \\
\hline Girl & $19(63,3)$ & $19(59,4)$ & \\
\hline Age, n $(\%)$, mean (SD), year & $11,48(3,81)$ & $11,83(3,37)$ & $0,789^{\mathrm{b}}$ \\
\hline $2-<6$ year & $3(10)$ & $2(6,2)$ & \\
\hline $6-<12$ year & $8(26,67)$ & $13(40,6)$ & \\
\hline 12- 18 year & $19(63,3)$ & $17(53,1)$ & \\
\hline \multicolumn{4}{|l|}{ Tribe, $\mathrm{n}(\%)$} \\
\hline Aceh & $4(13,3)$ & $4(12,5)$ & \multirow[t]{8}{*}{$0,746^{\mathrm{c}}$} \\
\hline Batak & $12(40)$ & $13(40,6)$ & \\
\hline India & $1(3,3)$ & 0 & \\
\hline Java & $3(10)$ & $4(12,5)$ & \\
\hline Malay & $5(16,7)$ & $6(18,8)$ & \\
\hline Minang & $3(10)$ & $4(12,5)$ & \\
\hline Papua & $2(6,7)$ & 0 & \\
\hline Tionghoa & 0 & $1(3,1)$ & \\
\hline \multicolumn{4}{|l|}{ Socioeconomic, n (\%) } \\
\hline Less & $3(10)$ & $4(12,5)$ & \multirow[t]{2}{*}{$1,000^{\mathrm{d}}$} \\
\hline Improved & $27(90)$ & $28(87,5)$ & \\
\hline \multicolumn{4}{|l|}{ Education, n (\%) } \\
\hline TK & $2(6,7)$ & $2(6,3)$ & \multirow[t]{5}{*}{$0,999^{c}$} \\
\hline $\mathrm{SD}$ & $10(33,3)$ & $11(34,4)$ & \\
\hline SMP & $11(36,7)$ & $11(34,4)$ & \\
\hline SMA & $5(16,7)$ & $6(18,8)$ & \\
\hline College & $2(6,7)$ & $2(6,3)$ & \\
\hline \multicolumn{4}{|l|}{ Pendidikan Ayah, n (\%) } \\
\hline SMA & $5(16,7)$ & $7(21,9)$ & \multirow[t]{2}{*}{$0,604^{\mathrm{a}}$} \\
\hline Perguruan Tinggi & $25(83,3)$ & $25(78,1)$ & \\
\hline \multicolumn{4}{|l|}{ Pendidikan Ibu, n (\%) } \\
\hline SMA & $2(6,7)$ & $2(6,3)$ & \multirow[t]{2}{*}{$1,000^{\mathrm{d}}$} \\
\hline Perguruan Tinggi & $28(93,3)$ & $30(93,8)$ & \\
\hline \multicolumn{4}{|l|}{ Father's Occupation, n (\%) } \\
\hline Employees & $15(50)$ & $19(59,4)$ & \multirow[t]{5}{*}{$0,788^{\mathrm{c}}$} \\
\hline Farmer & $2(6,7)$ & $1(3,1)$ & \\
\hline Government employee & $4(13,3)$ & $2(6,3)$ & \\
\hline Army/Police & $1(3,3)$ & $2(6,3)$ & \\
\hline Enterpreneur & $8(26,7)$ & $8(25)$ & \\
\hline \multicolumn{4}{|l|}{ Mother's Occupation, n (\%) } \\
\hline Employees & $8(26,7)$ & $14(43,8)$ & \multirow[t]{5}{*}{$0,381^{\mathrm{c}}$} \\
\hline Farmer & $4(13,3)$ & $1(3,1)$ & \\
\hline Government employee & $8(26,7)$ & $5(15,6)$ & \\
\hline Army/Police & $6(20)$ & $7(21,9)$ & \\
\hline Enterpreneur & $4(13,3)$ & $5(15,6)$ & \\
\hline \multicolumn{4}{|l|}{ Family History, n (\%) } \\
\hline Yes & $22(73,3)$ & $20(62,5)$ & \multirow[t]{2}{*}{$0,362^{\mathrm{a}}$} \\
\hline No & $8(26,7)$ & $12(37,5)$ & \\
\hline
\end{tabular}

${ }^{\mathrm{a}}$ Chi square, ${ }^{\mathrm{b}}$ Mann Whitney, ${ }^{\mathrm{c}}$ Kruskal Wallis, ${ }^{\mathrm{d}}$ Fischer's Exact

Table 2. Clinical Characteristics of Subjects.

\begin{tabular}{|c|c|c|c|}
\hline \multirow{2}{*}{ Characteristics } & \multicolumn{2}{|c|}{ H. pylori } & \multirow{2}{*}{$\mathbf{p}$} \\
\hline & $(+) n=30$ & $(-) n=32$ & \\
\hline Weight, Mean(SD), kg & $37,10(14,27)$ & $37,08(9,86)$ & $0,995^{\mathrm{a}}$ \\
\hline Height, Mean(SD), cm & $138,53(21,33)$ & $136,5(16,5)$ & $0,587^{\mathrm{b}}$ \\
\hline \multicolumn{4}{|l|}{ Symptoms, n (\%) } \\
\hline Nausea & 0 & $3(9,4)$ & $0,135^{\mathrm{c}}$ \\
\hline Vomit & $8(26,7)$ & $3(9,4)$ & \\
\hline Vomiting blood & $5(16,7)$ & $7(21,9)$ & \\
\hline Recurrent abdominal pain & $17(56,7)$ & $19(59,3)$ & \\
\hline
\end{tabular}

${ }^{\mathrm{a}}$ T Indepedent, ${ }^{\mathrm{b}}$ Mann Whitney, ${ }^{\mathrm{c}}$ Kruskal Wallis 
The relationship of CRP level to H.pylori infection shows in table 3, the mean CRP in children with positive $\mathrm{H}$. pylori infection was $36.78 \mathrm{mg} / \mathrm{dL}(\mathrm{SD}=20.93 \mathrm{mg} / \mathrm{dL}$ ) and the mean CRP in the group of children with negative $\mathrm{H}$. pylori infection was $11.73 \mathrm{mg} / \mathrm{dL}(\mathrm{SD}=5.29) . \mathrm{mg} / \mathrm{dL})$. By using the Mann Whitney test, it was found that there was a significant difference in the mean CRP between the two study groups ( $\mathrm{p}<0.001)$.

Table 3 Differences in CRP Levels Based on H. pylori infection

\begin{tabular}{lcc}
\hline & \multicolumn{2}{c}{ H. pylori } \\
\cline { 2 - 3 } & $(\mathbf{+}) \mathbf{n}=\mathbf{3 2}$ & $\mathbf{( - )} \mathbf{n}=\mathbf{2 2}$ \\
\hline CRP, mg/dL & $\mathbf{p}^{\mathbf{a}}$ \\
Mean & 36,78 & 11,73 \\
Median & 25,8 & 11,2 \\
SD & 20,93 & 5,29 \\
Min - max & $15-84$ & $5,5-30,20$ \\
${ }^{a}$ Mann Whitney & &
\end{tabular}

\section{DISCUSSION}

The results of the CLO examination found that 30 children with gastritis showed H. pylori infection and 32 children without $\mathrm{H}$. pylori infection. $30.2 \%$ were male and $69.8 \%$ female and in the group without $\mathrm{H}$. pylori infection, $36.1 \%$ were male and $63.9 \%$ female and there was no significant difference $(\mathrm{p}=0.43$ ) (Alimohammadi, et al., 2016). A case-control study by Supriatmo in Medan on 34 H.pylori positive children, with a control of 34 H.pylori negative children reported positive H.pylori were 13 boys $(38.2 \%)$ and 21 girls $(61.7 \%)$, while in the negative H.pylori group there were 12 boys (35.2\%) and 22 girls (64.7\%) (supriatmo, et al., 2020). A study in 1998 on 245 children reported $31 \%$ with $H$. pylori infection with the same frequency of $H$. pylori infection in male and female sexes ( $\mathrm{p}=0.704$ ) (Fiedorek, et al., 1991).

In previous studies it was reported that the prevalence of $H$. pylori infection was higher in women than in men. This is due to hormonal differences and the role of oxytocin in gastric evacuation. However, this difference was not statistically significant ( $\mathrm{p}=0.268$ ) (Uwan, et al. 2016). In this study, children with H.pylori infection were 11 children $(36.7 \%)$ and 19 children (63.3\%). While children without H.pylori infection were 13 children $(40.6 \%)$ and 19 children $(59.4 \%)$. There was no difference in the proportion of sex in the two study groups $(\mathrm{p}=0.479)$.

A prospective study in Saudi Arabia that was conducted for 3 years on 151 children with H. pylori infection reported an association between age group and the occurrence of H. pylori infection $(p<0.0001)$. In addition, this study also reported that the age group 3-6 years had a 7.9 times tendency to experience H. pylori infection compared to the age group under 3 years (Hasosah, et al. 2014). In a retrospective study conducted in Iran on 248 children aged 0-18 years who had endoscopic examination, as many as 82 children (33\%) infected with $H$. pylori with a mean age of $13.51 \pm 2.79$ years and a mean age of $13.51 \pm 2.79$ years. the mean age of patients without $H$. pylori infection was $13.12 \pm 3.32$ years $(p=0.36)$. The study stated that the prevalence of $H$. pylori infection increased with age $(\mathrm{p}<0.05)$ (Alimohamadi, et al., 2016). Another study that also reported an increase in prevalence with age, the H. pylori infection group increased from $24 \%$ at the age of 3-5 years to $45 \%$ at the age of 16-20 years (Fiedorek, et al., 1991).

Different results were obtained in a study conducted on 60 pediatric patients, it was reported that the mean age of $H$. pylori infection was $8.5 \pm 1.65$ years and there was no significant relationship between age and H. pylori infection $(p=0.743)$. This result is due to the fact that most of the patients who come are in the age group 7-10 years with sporadic cases at a younger age (Hagag, et al., 2018). In this study, the mean age of children with gastritis with $\mathrm{H}$. pylori infection was 11.48 years and the mean age of children with gastritis without $\mathrm{H}$. pylori infection was 11.83 years and there was no significant relationship $(\mathrm{p}=0.789)$.

In a study of 203 adults in Pontianak in 2016, H. pylori infection was found to be $40.9 \%$ using the rapid urea test and histopathology methods. The study found that the prevalence of H. pylori infection in the Chinese was $14.3 \%$ higher than the Dayak ethnic group. This study reported that ethnicity was associated with the incidence of $\mathrm{H}$. pylori $(\mathrm{p}=0.038)$. However, there were no significant differences in epidemiological characteristics between the two tribes. In addition, in one study in Jakarta, H. pylori infection was found in $80.9 \%$ of patients and $38.1 \%$ were ethnic Batak. The prevalence of certain ethnicities is higher than that of other ethnicities, which can theoretically be explained by migration theory. This theory explains that an ethnic originating from an area with a high prevalence will carry H. pylori infection to their offspring at the place of 
migration. Another theory known as the transmission theory explains that H. pylori infection does not only occur due to close contact between family and community members, but contact must also occur in the long term from childhood. Genetic factors can also play a role in the high incidence of $\mathrm{H}$. pylori infection in certain ethnicities (Uwan, et al. 2016). In this study, the Batak tribe was dominant in two groups, namely 12 children (40\%) in the group with $\mathrm{H}$. pylori infection and 13 children (40.6\%) in the group without H. pylori infection but there was no difference in the proportion of ethnic groups $(\mathrm{p}=0.746)$ in two groups

A study in Saudi Arabia reported a significant relationship between socioeconomic status and the occurrence of $\mathrm{H}$. pylori infection $(\mathrm{p}$ value $=0.016$ ) and $\mathrm{H}$. pylori infection was mostly in subjects with low socioeconomic status (Hasosah, et al. 2014). In a study in Poland, it was reported that 3,546 samples were children aged 0-18 years out of 6,565 samples. The results of this study reported a higher infection rate in children from underprivileged families so that low socioeconomic status influenced H. pylori infection (Laszweicz, et al. 2014). In this study, it was also reported that the dominant status in both groups was good economic status, and there was no significant relationship between socioeconomic status and the incidence of H. pylori infection $(p=1.00)$. This is because the father's work and mother's work are mostly employees so that the socio-economic status is good.

The education level of children in this study was mostly junior high school with 11 children (36.7\%) in the positive H. pylori infection group, and elementary and junior high school education in the negative H. pylori infection group as many as 11 children $(34.4 \%)$. The education level of the subjects' parents was mostly college $(88 \%)$ in the positive H. pylori infection group, but there was no significant relationship between the children's education level $(\mathrm{p}=0.999)$ and the parents' education level $(\mathrm{p}=0.604$ and 1.00). with H pylori infection. Research in the United States reports that infection rates are higher at levels of education below high school and low incomes. The high prevalence of $\mathrm{H}$. pylori infection in groups with low levels of education is associated with high socioeconomic, sanitation, and residential density levels. These conditions can lead to very close contact between individuals and easier transmission of disease agents (Uwan, et al., 2016).

A study in Malaysia on 159 children with $\mathrm{H}$. pylori seropositive found $31.6 \%$ of children with a low level of paternal education and $14.3 \%$ of children with a high level of paternal education, but no significant difference was found between the education level of H. pylori seropositivity (Boey, et al. 1999). Another study reported children with mothers without education history had 2.5 times higher risk of $H$. pylori infection $(\mathrm{p}<0.001)$ (Mahalanabis, et al., 1996).

A study in Taiwan reported that there was no significant relationship between weight and height with the occurrence of H. pylori infection. $(\mathrm{p}=0.847)(\mathrm{p}=0.132) 49$ In this study there was no significant relationship between body weight and the occurrence of $\mathrm{H}$. pylori infection $(\mathrm{p}=0.995)$ and the incidence of $\mathrm{H}$. pylori infection was also not significantly associated with height $(\mathrm{p}=0.587$ ). In addition, a study conducted in 1996 also showed that H. pylori infection was not associated with nutritional status calculated by weight/age (Mahalanabis, et al., 1996). In a study of adults in China, it was reported that the obese population had the highest H. pylori infection rate compared to normal nutritional status and overweight at $51 \%$. The explanation for this is still uncertain but it is suspected that the gastrointestinal hormones ghrelin and leptin are involved in the balance of metabolic and energy control. Ghrelin is produced in the stomach and stimulates food intake and leptin has the opposite effect. Studies have reported lower serum leptin and ghrelin levels in patients with H. pylori infection. A review study showed a negative correlation between the prevalence of $\mathrm{H}$. pylori infection and obesity in developing countries (Chen H, et al., 2019).

In a study in Saudi Arabia, children infected with H. pylori had a significant relationship with upper gastrointestinal symptoms, namely recurrent abdominal pain $(\mathrm{p}<0.001)$, anorexia ( $\mathrm{p}$ value $<0.001)$, nausea $(\mathrm{p}=$ 0.026), compared to children without H. pylori (Habib, et al., 2014). This is in line with a study in adults in Thailand which showed a significant association between abdominal pain symptoms and H. pylori infection (Tongtawee, et al., 2016). In this study, the most clinical symptoms in the two groups were recurrent abdominal pain, namely 17 people (56.7\%) in the gastritis group with H. pylori infection and 19 people (59.3\%) in the gastritis group without $\mathrm{H}$. pylori infection. The results of this study are in accordance with previous studies, namely the dominant gastrointestinal symptom is abdominal pain in gastritis children who are infected with H. pylori and those who are not infected, so that H. pylori infection generally does not have typical symptoms. In addition, this study also reported that there was no significant relationship between the clinical symptoms of gastritis and the 
incidence of $\mathrm{H}$. pylori infection, where the symptoms were nausea, vomiting, vomiting blood and abdominal pain $(\mathrm{p}=0.135)$ (Tina, et al., 2013).

CRP is one of the acute phase proteins found in normal serum, although in very small concentrations. Due to its presence in the blood, CRP can be used to help diagnose and follow-up various inflammatory and traumatic conditions (Rifai, et al., 2006). CRP in plasma produced by liver hepatocytes is mainly affected by stimulation of pro-inflammatory cytokines such as interleukins (IL) and tumor necroting factor (TNF ). CRP synthesis in the liver takes place very quickly after stimulation, the concentration can increase and reach a peak after 24-48 hours (Ingle, et al., 2011). ${ }^{26}$

H. pylori can cause a prolonged inflammation and immune response by releasing various cytotoxic substances, which can cause chronic gastritis, peptic ulcer, and gastric cancer. Clinical manifestations can be caused by mechanisms due to direct and indirect effects of $\mathrm{H}$. pylori infection. Direct effects on the vascular wall cause endothelial damage and dysfunction due to circulating endotoxins, resulting in local inflammation. Indirect effects can be an increase in inflammatory mediators, the production of cross-reactive antibodies, all of which can stimulate the formation of CRP in liver cells (Alimohammadi, et al., 2016).

A study conducted in Germany on 90 children, to see the relationship of Helicobacter pylori infection to CRP values and vitamin B status. In this study used Urea Breath Test (UBT) and stool test in establishing H. pylori infection. In this study reported 69 children with H.pylori positive and 21 children with H.pylori negative. In that study, it was reported that the mean CRP value in children with $\mathrm{H}$. pylori positive was $3.72 \pm 2.53$ and the mean CRP value in children with $\mathrm{H}$. pylori negative was $2.76 \pm 0.97$. In this study, it was reported that there was a significant difference between the CRP values in positive and negative H.pylori ( $p=0.011$ ) (Stettin, et al., 2008). However, other studies have obtained different results. In a study conducted on 489 dyspeptic patients, it was found that the CRP value was higher in the positive H.pylori group than the negative H.pylori group, but there was no significant difference $(\mathrm{p}=0.817$ ) (Andreola, et al., 2016). The same thing was also reported in the study in 453 patients that CRP values were significantly higher in seropositive patients than in seronegative patients (Alimohammadin, et al., 2016). This indicates that H. pylori infection is closely related to CRP values. Several previous studies have shown that the CRP value will decrease significantly in patients who have received H.pylori eradication therapy (Andreola, et al., 2016). In this study, it was reported that the mean CRP value in the H.pylori positive group was 36.78 , and the mean CRP value in the H.pylori group. pylori negative was 11.73 so there was a significant difference in the mean between the two study groups.

This study has several limitations, namely not doing histopathological biopsy and also not doing microorganism culture. However, in children, histopathological biopsy examination is not only difficult and often results in negative results, there is also a risk of bleeding and infection at the collection site. While the culture of microorganisms requires more expensive costs and longer time.

This study was conducted by endoscopic examination and CLO, so that it can provide an overview of the proportion and clinical symptoms as well as the value of CRP in childhood gastritis. Not all education centers and hospitals are capable of performing endoscopic procedures

\section{CONCLUSION}

In this study, there was a relationship between the value of C-reactive Protein (CRP) in gastritis in children with or without Helicobacter pylori infection. In this study, it was found that the prevalence of women was higher than men, and the prevalence increased by age for the incidence of H.pylori infection. The dominant clinical symptom found is recurrent abdominal pain. The mean value of CRP in H.pylori infection was 36.78, while in the group without H.pylori infection it was 11.73 , and there was a significant difference between the two groups.

\section{SUGGESTION}

In this study, there was no significant relationship between baseline characteristics and clinical characteristics, but there was a significant relationship between CRP values and H. pylori infection in children. This study shows that children who present with clinical symptoms of gastritis are not always caused by H. pylori infection. Also, this study has not assessed the patient's hygiene and environmental factors, where children generally have poor levels of personal and environmental hygiene. This study used a sample aged 2-18 years. According to several studies, the frequency of occurrence of $\mathrm{H}$. pylori infection increases with age. So it is necessary to do further research on certain age groups and socioeconomic status so that the data is more homogeneous. 


\section{Acknowledgements}

The author thanks to all clinical staff of Pediatric Gastroenterology, Universitas Sumatera Utara, who were involved and contributed for the completion of this study.

\section{REFERENCES}

1. Alimohammadi, H., Fouladi, N., Salehzadeh, F., Alipour, S.,A.,2016. Javadi MS. Childhood recurrent abdominal pain and Helicobacter pylori infection, Islamic Republic of Iran. Eastern Mediterranean Journal 22, p.860.

2. Altun, E., Yilzid, A., Cevik, C., Turan, G., 2019 The role of high sensitive C-reactive protein and histopatological evaluation in chronic gastritis patients with or without helicobacer pylori infection. Acta Cirurgica Brasileira34, p.1.

3. Andreola, H.,F., Bona, L.,R., Sander, G.,B., Mazzoleni, L.,E., Tavares, R.,G., Prolla, J.,C., 2016. Lack of association between helicobacter pylori's virulence and increases serum c-reactive protein levels in functional dyspeptic. Arquivos de Gastroenterologia 53, p.49.

4. Boey, C.,C.,M., Goh, K.,L., Lee, W.,S., Parasakthi,. 1999. Seroprevalence of Helicobacter pylori infection in Malaysian children: Evidence for ethnic differences in childhood. Jornal of Paediatric and Child Health 35, p.151.

5. Briggs, M.,S., Givens, D,. L., Schmitt, L.,C., Taylor, C., 2013. Relations of C-reactive protein and obesity to the prevalence and the odds of reporting low back pain. Archives of Physical Medicine and Rehabilitation 94, p.745.

6. Chen, H., Chen, M., Shih, S., Wang, H., Lin, I., Bair, M,. et al. 2014. Socioeconomic status, personal habits, and prevalence of Helicobacter pylori infection in the inhabitants of Lanyu. Journal of the Formosan Medical Association 113, p. 278.

7. Fiedorek, S., Malaty, H.,M., Evans, D.,L., Pumphrey, C.,L., Casteel, H,.B., Evans, D.,J., et al. 1991. Factors influencing the epidemiology of Helicobacter pylori infection in children. Pediatrics 88, p. 578.

8. Guclu, M., Agan, A., F., 2017. Association of severity of Helicobacter pylori infection with peripheral blood neutrophil to lymphocyte ratio and mean platelet volume. Euroasian Journal of Hepato-Gastroenterology 7, p. 11.

9. Hagag, A.,A., Amin, S.,M., Emara, M.,H., Abo-resha, S.,E., 2018. Gastric mucosal oxidative stress markers in children with Helicobacter Pylori infection. Infectious Disorders- Drug Targets 18, p. 60.

10. Hasosah M, Satti M, Shehzad A, Alsahafi A, Sukkar G, Alzaben A, et al. Prevalence and risk factors of Helicobacter pylori infection in Saudi children: A three-year prospective controlled study. John Wiley \& Sons Ltd, Helicobacter. 2014; 20:56-63.

11. Hasosah, M., Satti, M., Shehzad, A., Alsahafi, A., Sukkar, G., Alzaben, A., et al. 2014. Prevalence and risk factors of Helicobacter pylori infection in Saudi children: A three-year prospective controlled study. John Wiley \& Sons Ltd, Helicobacter 20, p. 56.

12. Habib, H., S., Hegazi, M., A., Murad, H., A., Amir, E., M., Halawa, T., F., El-Deek, B., S., et.al 2014. Unique features and risk factors of Helicobacter pylori infection at the main children's intermediate school in Rabigh, Saudi Arabia. Indian Society of Gastroenterology.

13. Hegar B., 2000. Infeksi helicobacter pylori pada anak. Sari pediatric 2, p. 82.

14. Ingle, P.,V., Patel, D.,M., 2011. C-reactive protein in various disease condition-an overview. Asian journal of pharmaceutical and clinical research 4 , p. 9.

15. Kingsley, A., Jones, V., 2008. Diagnosing wound infection: the use of C-reactive protein. Wounds UK. 2008;4(4):32-46.

16. Laszweicz, W., Iwanczak, F., Iwanczak, B., 2014. Seroprevalence of Helicobacter pylori infection in Polish children and adults depending on socioeconomic status and living conditions. Advances in Medical Sciences, p. 147.

17. Mahalanabis, D., Rahman, M,.M., Sarker, S.,A., Bardhan, P.,K., Hildebrand, P., Beglinger, C., et al 1996. . Helicobacter pylori infection in the young in Bangladesh: prevalence, socioeconomic and nutritional aspects. International Journal of Epidemiology 25, p. 894.

18. Plunkett, A,. Beattie, R.,M., 2005. Recurrent abdominal pain in childhood. Journal of the Royal Society of Medicine 98, p. 101.

19. Raut, S,.C., Patil, V,.W,. Dalvi, S,.M,. Bakhshi, G,. D., 2005. Helicobacter pylori gastritis, apresequeale to coronary plaque. Clinics and practice 5, p. 28.

20. Ruggiero, P., 2010. Helicobacter pylori and inflammation. Current pharmaceutical design 16, p. 4225.

21. Rifai, N., 2006. Analytic Issues for Clinical Use of C-Reactive Protein. In: Morrow DA, ed. Cardiovascular biomarkers pathophysiology and disease management. Humana press, p. 229-34. 
22. Saribas, S., Kocazeybek, B., Aslan, M., Altun, S., Seyhun, Y., Oner, Y.,A., et al. 2004. Do procalcitonin and C-reactive protein levels have a place in the diagnosis and follow up of Helicobacter pylori infections?. Journal of medical microbiology 53, p. 639.

23. Sierra, D., Wood, M., Kolli, S., Felipez, L.,M., Pediatric gastritis, gastropathy, and peptic ulcer disease. American Academy of Pediatrics Publications 39, p. 542.

24. Stettin, D., Waldmann, A., Strohle, A., Hahn, A., 2008. Association between helicobacter pylori infection, C-reactve protein and status of B vitamins. Advance in Medical Sciences 53, p. 205.

25. Supriatmo., Siregar, G.,A., Nasution, I.,P.,A., Ramayani, O.,R., 2020. Interleukin-8 heterozygous polymorphism $(-125 \mathrm{~T} / \mathrm{A}$ and $+781 \mathrm{C} / \mathrm{T})$ increases the risk of helicobacter pylori- infection gastritis in children: a case control study. Medicinski Glasnic 17, p. 383.

26. Tina, R., Dwi, P., Herry, G., 2013. Efektivitas terapi infeksi Helicobacer pylori pada anak dengan keluhan sakit perut berulang setelah satu tahun terapi eradikasi. Sari Pediatri, p. 111.

27. Tongtawee, T., Kaewpitoon, S., Kaewpitoon, N., Dechsukhum, D., Leeanansaksiri, W., Loyd, R.,A., 2016. Characteristics and risk factors of Helicobacter pylori associated gastritis: A prospective cross-sectional study in Northeast Thailand. Gastroenterology Research and Practice, p. 1.

28. Uwan, W., B., Syam, A., F., Lesmana, C., R., A., Rumende, C., M., 2016. Perbedaan prevalensi infeksi Helicobacter pylori antara etnis Tionghoa dan Dayak dengan sindrom dispepsia. J Penyakit Dalam Indonesia 3, p. 29.

29. Vermeire, S., Assche, G.,V., Rutgeerts, P., 2005. The role of C-reactive protein as an inflammatory marker in gastrointestinal disease. Nature clinical practice 2, p. 580.

30. Xu, X., Li, W., Qin, L., Yang, W., Yu, G., Wei, Q., 2019. Relationship between Helicobacter pylori infection and obesity in Chinese adults: A systematic review with meta-analysis. PloS One. 